\title{
Intellectual Capital Investment and Firm Performance of the Malaysian Energy Sector: A New Perspective From a Nonlinearity Test
}

\author{
Jawad Asif ${ }^{1}$, Irene Wei Kiong Ting ${ }^{1}$ (D), Qian Long Kweh ${ }^{2}$ \\ ${ }^{1}$ Faculty of Industrial Management, Universiti Malaysia Pahang, Malaysia, 2 Faculty of Management, Canadian University Dubai, United Arab Emirates \\ Keywords: intellectual capital investment, firm performance, malaysian energy sector \\ https://doi.org/10.46557/001c.13622
}

\section{Energy RESEARCH LETTERS}

Vol. 1, Issue 3, 2020

This study examines the association between intellectual capital investment and firm performance of the Malaysian energy sector. A non-linear relationship between intellectual capital investment and firm performance is established. At low levels of intellectual capital investment, increasing investments in intellectual capital improve firm performance. After a cut-off point, increments to intellectual capital investment reduce firm performance.

\section{Introduction}

Intellectual capital (IC) plays a crucial role in a firm's strategic management. IC is considered the foremost resource because of its features, such as being valuable, scarce, inimitable, and non-substitutable. Edvinsson and Sullivan (1996) suggest that the profitability of firms is mainly derived through their IC. According to the International Integration Reporting Council, the value of a firm is created through its external environment, relationships, and various resources. Therefore, a firm's products, people, environment, and processes play a significant role in its successful strategy. However, Li and Zhao (2018) emphasize that the association between IC and firm performance is a black box and it is not straightforward. In other words, IC is linked to both firm costs and benefits. To further investigate this issue, our paper attempts to explore how the IC investment level affects performance of firms listed in the energy sector of Bursa Malaysia for the period 2009-2018.

The phenomenon of IC helps stimulate innovative ideas and advanced procedures and systems in the energy sector of Malaysia by generating and transmitting energy-related products to different stakeholders. Furthermore, the Malaysian government aims to promote sustainable growth through proper utilization of IC investments. Similarly, the Eleventh Malaysia Plan 2016-2020 aims to accelerate the development of human capital; thereby, facilitating sustainable economic growth. This research attempts to contribute to the literature by investigating the nonlinear effects of IC investment on firm performance in the Malaysian energy sector. The nonlinear impacts are observed in IC, as well as in its constituents, namely, human capital and capital employed.

The findings of this study extend the literature from two perspectives. First, this study utilizes a unique sample of energy sector firms to investigate the impact of IC investment on firm performance. Previous studies on Malaysia do not consider energy firms. By doing so, we provide energy-specific insights on the relation between IC investment and firm performance. Second, in contrast to Huang and Liu (2005), who only address innovation capital and information technology as components of IC, we explore the linearity and non-linearity relation between IC investments (human capital, structural capital and relation capital) and firm performance. Our goal is to offer findings that will provide inspiration to future studies in assessing the impact of IC investment on firm performance.

The paper is organized as follows. The hypotheses are developed in Section 2. Section 3 presents the methods employed by this study. Section 4 contains results and the final section offers concluding remarks.

\section{Literature Review and Hypotheses Development}

Sardo and Serrasqueiro (2018) suggest that IC prompts innovation and growth of firms. Greater investment in IC resources helps firms convey commitment toward their longevity. In this way, firms can benefit from building a good reputation among their competitors. Similarly, firms facilitate their acquisition of new knowledge by developing collaborations (Kianto et al., 2017). Smriti and Das (2018) further confirm the contribution of IC to a firm's value creation. Additionally, Young, Su, Fang, and Fang (2009) point out that human and physical capital are the main sources of a firm's wealth creation. We infer that the profitability of firms is mostly due to the intangible resources of an organization in the energy sector. Accordingly, we hypothesize that IC investments are positively related to firm performance.

Hypothesis 1a: Intellectual capital investment is positively associated with firm performance in the energy sector.

IC-related investment may become a curse for firms when it generates detrimental effects. Prior research has found that firms are constrained to accumulate IC investments because of certain costs associated with IC resources. Firms, for instance, must undergo an extensive waiting period before experiencing benefits from IC investments (Kweh et al., 2019), and such a wait is considered a time cost. The costs associated with IC investments are substantial as well as risky, and this situation might produce a negative firm return. Subramanian and van de Vrande (2019) posit that huge IC investments generate high costs in terms of new product development. They further argue that these long-term investments are difficult to conclude once initiated because of their substantial initial costs.

Hypothesis 1b: Intellectual capital investment is negatively associated with firm performance in the energy sector. 
Table 1: Regression results - total and individual linear effects

\begin{tabular}{|c|c|c|c|c|c|}
\hline & \multicolumn{3}{|c|}{ Model 1} & \multicolumn{2}{|c|}{ Model 2} \\
\hline & \multicolumn{3}{|c|}{ Panel Regression } & \multicolumn{2}{|c|}{ Pooled-OLS } \\
\hline & Coefficient & & $t$-Stat. & Coefficient & $t$-Stat. \\
\hline Intercept & 0.1135 & & 1.6467 & $-0.1091^{* * *}$ & -4.5598 \\
\hline IC & $0.0048^{* * *}$ & & 5.2179 & & \\
\hline$H C E$ & & & & $0.0019^{* * *}$ & 2.7028 \\
\hline$S C E$ & & & & 0.0068 & 1.1992 \\
\hline CEE & & & & $0.2221^{* * *}$ & 6.3172 \\
\hline FAGE & $-0.0551^{* *}$ & & -2.2786 & $0.0207^{* * *}$ & 2.6016 \\
\hline$C R$ & $0.0142^{* *}$ & & 2.3012 & $0.0171^{* * *}$ & 4.0182 \\
\hline Adjusted $\mathrm{R}^{2}$ & & 0.2361 & & & \\
\hline F-statistic & & $3.4934^{* * *}$ & & & \\
\hline
\end{tabular}

The dependent variable is $R O A$ and it is an internal measure of firm performance. It is computed as the ratio of net earnings to total assets of firms. The aggregate of $H C E$, SCE, and $C E E$ is named IC. HCE is obtained through dividing value added (VA) by human capital (HC), where VA is computed by taking the difference of operational revenues and expenses. $H C$ proxies for employees' remuneration. SCE is the quotient of VA to structural capital (SC), where $S C$ is the difference between VA and HC. CEE is computed by dividing VA by CE, where net assets are considered as the proxy for CE. FAGE is computed as the logarithm of the number of years since a firm was established. $C R$ is computed by dividing a firm's short-term assets by its short-term liabilities. Finally, ${ }^{* * * *}$ and ${ }^{* *}$ denote that coefficients are significant at the $1 \%$ and $5 \%$ levels, respectively.

\section{Methods}

\subsection{Sample Selection}

Data on companies belonging to the energy sector of Malaysia are hand collected from company annual reports covering the period 2009 to 2018. The rationale for using this time period is to dissociate the sample from the effects of the 2007-2008 subprime financial crisis, as highlighted by McManus, Floyd, Majid, and Kassim (2009). Samples with missing observations were excluded, and the final dataset consists of an unbalanced panel comprised of 372 firms.

\subsection{Measurement of Variables}

The IC and its components are utilized as main testing variables. The $I C$ and its components, namely, human capital efficiency (HCE), structural capital efficiency (SCE), and capital employed efficiency (CEE) are derived from Pulic (2000). The model has certain features that distinguish it from other methods such as simplicity, data availability, comparability, and wide application. The quotient of value added (VA) and human capital $(H C)$ is named as $H C E$, where $V A$ is computed by taking the difference of operational revenues and expenses. $H C$ is proxied by the remuneration of employees. The fraction of $V A$ to structural capital $(S C)$ is named $S C E$, where $S C$ is computed as the difference between VA and HC. CEE is computed by dividing VA by $C E$, where net assets are considered as a proxy for $C E$.

Return on assets (ROA) is an internal measure of firm performance and is computed as the ratio of net earnings to total assets of firms. Firm age (FAGE) and current ratio $(C R)$ are control variables. FAGE is computed as the logarithm of the number of years since a firm was established. Finally, $C R$ is quantified by dividing a firm's short-term assets by its short-term liabilities.

\subsection{Empirical Models}

The Lagrange Multiplier (LM) test is employed to decide between pooled-OLS and panel data regression models. The
Breusch-Godfrey Serial Correlation LM test indicates that panel regression (fixed effect model with the Hausman test $(p<0.05)$ is applicable for IC and pooled-OLS is suitable for $I C$ components. This study thus applies either panel data regression or ordinary least squares in assessing the impacts of $I C$ and its constituents on firm performance. Specifically, the following empirical models are developed to estimate linear effects:

$$
\begin{aligned}
R O A_{i t}= & \beta_{0}+\beta_{1} I C_{i t}+\beta_{2} F A G E_{i t}+\beta_{3} C R_{i t}+\varepsilon_{i t} \\
R O A_{i t}= & \beta_{0}+\beta_{1} H C E_{i t}+\beta_{2} S C E_{i t}+\beta_{3} C E E_{i t} \\
& +\beta_{4} F A G E_{i t}+\beta_{5} C R_{i t}+\varepsilon_{i t}
\end{aligned}
$$

From Equations (1) and (2), Equations (3) and (4) are specified by including the respective squares of $I C$ and IC components to capture the nonlinear effects of $I C$ investments on firm performance. These models are as follows.

$$
\begin{aligned}
R O A_{i t}= & \beta_{0}+\beta_{1} I C_{i t}+\beta_{2} I C_{i t}^{2}+\beta_{3} F A G E_{i t}+\beta_{4} C R_{i t}+\varepsilon_{i t} \\
R O A_{i t}= & \beta_{0}+\beta_{1} H C E_{i t}+\beta_{2} H C E_{i t}^{2}+\beta_{3} S C E_{i t}+\beta_{4} S C E_{i t}^{2} \\
& +\beta_{5} C E E_{i t}+\beta_{6} C E E_{i t}^{2}+\beta_{7} F A G E_{i t}+\beta_{8} C R_{i t}+\varepsilon_{i t}
\end{aligned}
$$

\section{Findings}

In untabulated results of the Pearson correlation coefficients, we find that all coefficients are lower than 36 percent except for $H C E$ and $I C$, indicating that the multicollinearity issue does not exist between firm performance and the explanatory variables.

Table 1 presents the outcomes from regression models and reveals the linear relationship of $I C$ and its components with the dependent variable $R O A$. The results from Equation (1) show that IC plays a vital role in improving firm performance. These findings corroborate those of Smriti and Das (2018), who show that IC investment plays a crucial role in the generation of a company's wealth. Moreover, our findings suggest that $H C E$ and $C E E$ contribute to firm performance in the Malaysian energy sector. This result is consistent with Young, Su, Fang, and Fang (2009), who identify human and physical capital as the dominant source of financial performance for Malaysian firms.

This study also assesses the nonlinear association between IC investment and firm performance. Table 2 shows 
Table 2: Regression results - non-linear effects

\begin{tabular}{|c|c|c|c|c|}
\hline & \multicolumn{2}{|c|}{ Model 3} & \multicolumn{2}{|c|}{ Model 4} \\
\hline & \multicolumn{2}{|c|}{ Panel Regression } & \multicolumn{2}{|c|}{ Panel Regression } \\
\hline & Coefficient & $t$-Stat. & Coefficient & $t$-Stat. \\
\hline Intercept & $0.1099^{*}$ & 1.8209 & 0.0756 & 1.2279 \\
\hline IC & $0.0183^{* * *}$ & 11.6272 & & \\
\hline$I C^{2}$ & $-0.0003^{* * *}$ & -9.9848 & & \\
\hline$H C E$ & & & $0.0157^{* * *}$ & 8.5240 \\
\hline$H C E^{2}$ & & & $-0.0002^{* * *}$ & -7.6564 \\
\hline$S C E$ & & & 0.0070 & 1.2217 \\
\hline$S C E^{2}$ & & & -0.0011 & -0.8885 \\
\hline CEE & & & $0.2092^{* * *}$ & 3.4510 \\
\hline$C E E^{2}$ & & & $-0.0890^{*}$ & -1.9575 \\
\hline FAGE & $-0.0626^{* * *}$ & -2.9553 & $-0.0499^{* *}$ & -2.3362 \\
\hline$C R$ & $0.0138^{* *}$ & 2.5621 & $0.0136^{* *}$ & 2.5784 \\
\hline Adjusted $\mathrm{R}^{2}$ & & & & \\
\hline F-statistic & & & & \\
\hline
\end{tabular}

See notes to Table 1.

that $I C$ is statistically significant and positive, whereas the coefficient on $I C^{2}$ is statistically significant and negative. These results present the inverse U-shaped behavior of $I C$ investment on firm performance. At the initial stage, IC investment contributes remarkably to firm performance in a positive way. However, after a certain tangent point at a higher level of investment, its positive effect reverts to a negative impact.

Equation (4) uncovers nonlinear patterns of the individual elements of $I C$ in explaining firm performance. According to Table 2, HCE has a positive coefficient of 0.0157 , while the coefficient of $H C E^{2}$ is -0.0002 . Thus, a quadratic relationship exists between $H C E$ and firm performance. Consistently, the result of Equation (4) indicates a positive effect of $C E E$ and a negative effect of $C E E^{2}$. Those outcomes suggest that the higher the human capital and physical capital investment, the better the firm performance of the Malaysian public listed energy sector. However, firm performance is negatively affected by $H C E$ and $C E E$ after a cutoff point because $H C E$ and $C E E$ investments are more costly compared to returns. Again, both $S C E$ and $S C E^{2}$ are statistically insignificant, thereby confirming that $S C E$ is not an antecedent of firm performance. These results are consistent with those of Ting and Lean (2009) for the Malaysian market in relation to the financial sector.

\section{Conclusion}

Using Malaysian data, we show that intellectual capital and its constituents (human capital and capital employed) form an inverse U-shape relationship with energy sector firm performance. The structural capital shows no such linear and nonlinear relationship. In other words, the human capital and capital employed hamper firm performance after a certain cut-off point. The findings suggest that investors in energy firms should favor more input of physical and human capital. The results of this study are, thus, helpful for investors and policy legislators. Moreover, favorable policies should be introduced for prospective investors. Future studies should explore effectiveness of policies and investor returns in the Malaysian energy sector.

\section{Acknowledgements}

We would like to thank the Editor and anonymous reviewers of this journal for their valuable feedback in improving this version of the paper.

We would like to thank Universiti Malaysia Pahang, which financially supported this research (PGRS200308) 


\section{REFERENCES}

Edvinsson, L., \& Sullivan, P. (1996). Developing a model for managing intellectual capital. European Management Journal, 14(4), 356-364. https://doi.org/ $\underline{10.1016 / 0263-2373(96) 00022-9}$

Kianto, A., Sáenz, J., \& Aramburu, N. (2017). Knowledge-based human resource management practices, intellectual capital and innovation. Journal of Business Research, 81, 11-20. https://doi.org/10.10 16/j.jbusres.2017.07.018

Kweh, Q. L., Ting, I. W. K., Hanh, L. T. M., \& Zhang, C. (2019). Intellectual capital, governmental presence, and firm performance of publicly listed companies in Malaysia. International Journal of Learning and Intellectual Capital, 16(2), 193-211. htt ps://doi.org/10.1504/ijlic.2019.098932

Li, Y., \& Zhao, Z. (2018). The dynamic impact of intellectual capital on firm value: Evidence from China. Applied Economics Letters, 25(1), 19-23. http s://doi.org/10.1080/13504851.2017.1290769

McManus, J., Floyd, D., Majid, M. S. A., \& Kassim, S. H. (2009). Impact of the 2007 US financial crisis on the emerging equity markets. International Journal of Emerging Markets.

Pulic, A. (2000). VAIC ${ }^{\mathrm{TM}}$ an accounting tool for IC management. International Journal of Technology Management, 20(5-8), 702-714. https://doi.org/10.15 04/ijtm.2000.002891
Sardo, F., \& Serrasqueiro, Z. (2018). Intellectual capital, growth opportunities, and financial performance in European firms: Dynamic panel data analysis. Journal of Intellectual Capital, 19(4), 747-767. https://doi.org/10.1108/jic-07-2017-0099

Smriti, N., \& Das, N. (2018). The impact of intellectual capital on firm performance: A study of Indian firms listed in COSPI. Journal of Intellectual Capital, 19(5), 935-964. https://doi.org/10.1108/jic-1 1-2017-0156

Subramanian, A. M., \& van de Vrande, V. (2019). The role of intellectual capital in new product development: Can it become a liability? Journal of Operations Management, 65(6), 517-535. https://do i.org/10.1002/joom.1045

Ting, I. W. K., \& Lean, H. H. (2009). Intellectual capital performance of financial institutions in Malaysia. Journal of Intellectual Capital, 10(4), 588-599. https://doi.org/10.1108/1469193091099666 1

Young, C.-S., Su, H.-Y., Fang, S.-C., \& Fang, S.-R. (2009). Cross-country comparison of intellectual capital performance of commercial banks in Asian economies. The Service Industries Journal, 29(11), 1565-1579. https://doi.org/10.1080/02642060902793 $\underline{284}$ 